\title{
The Way Forward: Food Systems for Enabling Rural Prosperity and Nutrition Security
}

\subsection{INTRODUCTION}

Why is malnutrition so persistent in India despite the country's selfsufficiency in food production? This book explores this policy conundrum through the lens of its food systems. Laying out a formal exposition of the food systems, we flesh out the linkages between achieving equitable economic growth and agricultural development and improving nutrition outcomes: the bedrock of India's malnutrition challenge. This book adds to the literature by stringing together, for the first time, the inter-linkages between these overlapping themes. We highlight the importance of economic growth for the affordability of nutrition, agricultural development for nutrition availability and the role of improved nutrition access. In this chapter, we deliberate upon the importance of the type of regional development in propelling economic growth. We move away from a national framework to highlight variegated subnational development trajectories. We argue that regions which leveraged agriculture as the engine of growth-through commercialized and market-oriented agricultural systems - have fared better in addressing the problem of undernutrition. In this book, we have classified regional development patterns as lagging, agriculture-led and urbanizing. Agriculture-led growth states are those where a highly productive agricultural sector leads growth. Urbanizing states leveraged agricultural development to kickstart structural transformation (ST). Now their development is driven by non-agricultural growth

(C) The Author(s) 2019

P. Pingali et al., Transforming Food Systems for a Rising India, Palgrave Studies in Agricultural Economics and Food Policy, https://doi.org/10.1007/978-3-030-14409-8_11 
and urbanization. Urbanized states have largely succeeded in addressing the undernutrition problem, but are increasingly facing the problem of rising obesity and the rise in non-communicable disease incidence. Regions with lower agricultural productivity-lagging states-fare worse than the rest of the country and catch-up growth policies are of importance. In these areas, tackling undernutrition continues to remain the dominant nutrition challenge. Thus in this book, we argue that any policy on nutrition should consider these disparate subnational developmental patterns. The food systems approach provides us with an organizing framework to link the goals for economic growth, agricultural development and nutrition.

Taking the food systems approach, this book offers multiple policy recommendations. We bring agricultural sector-led developmental approach at the center of any policy formulation to ensure greater nutrition security and rural prosperity for greater welfare. Our policy recommendations are also tailored to the subnational variations in the process of structural transformation. While the share of agriculture in India's GDP has declined considerably, agriculture still employs a large share of the labor force. In some states, this is more so and those are the ones where developmental outcomes including malnutrition are poorer. National level policy goals were useful while formulating policies in the immediate aftermath of our independence from the British. In the seven decades that followed, states of India have exhibited distinct and disparate developmental patterns because of various factors which include climate, soil, water facilities among other factors. Despite agriculture being under the purview of state government, one unified national policy blind to the geographical variation and differences in resource endowments is likely to further widen these disparities. Our policy recommendations explicitly factor in these subnational contexts. For example (Table 11.1), we recommend that in the lagging regions, creating new comparative advantages for catch-up growth in agriculture, encouraging diversification of agricultural production systems and reducing undernutrition and hunger should be the main policy focus. For the states which fall under the category of agriculture-led, policy should prioritize agricultural diversification and commercialization and enabling adoption of sustainable agricultural production techniques. These states would continue to focus on their comparative advantage in agriculture but with a shift in emphasis from their traditional strength in staple grains to higher value crop and livestock production systems. In the urbanizing regions, the challenge lies in urban planning and developing strategies which support the process of commercialization of agriculture. The government should 
Table 11.1 Policies for enabling nutrition security and rural prosperity

\begin{tabular}{|c|c|c|c|}
\hline $\begin{array}{l}\text { Main goal: Enabling } \\
\text { nutrition security } \\
\text { and rural prosperity } \\
\text { by } 2050\end{array}$ & Lagging states & $\begin{array}{l}\text { Agriculture-led } \\
\text { states }\end{array}$ & Urbanizing states \\
\hline $\begin{array}{l}\text { Agricultural } \\
\text { development policies: } \\
\text { Increasing rural } \\
\text { prosperity and } \\
\text { nutrient availability }\end{array}$ & $\begin{array}{l}\text { Growing crops } \\
\text { based on } \\
\text { comparative } \\
\text { advantages provided } \\
\text { by agro-ecological } \\
\text { zones }\end{array}$ & $\begin{array}{l}\text { Sustainable } \\
\text { agriculture } \\
\text { production to } \\
\text { rectify input } \\
\text { overuse from staple } \\
\text { grain production }\end{array}$ & $\begin{array}{l}\text { Commercialization of } \\
\text { agricultural } \\
\text { production }\end{array}$ \\
\hline $\begin{array}{l}\text { Nutrition policies: } \\
\text { Improving nutrient } \\
\text { access and absorption } \\
\text { and labor productivity }\end{array}$ & $\begin{array}{l}\text { Reduction of } \\
\text { undernutrition, } \\
\text { communicable } \\
\text { diseases and hunger }\end{array}$ & $\begin{array}{l}\text { Reduction of over } \\
\text { nutrition, } \\
\text { non-communicable } \\
\text { diseases (NCDs) } \\
\text { and hunger }\end{array}$ & $\begin{array}{l}\text { Reduction of } \\
\text { over-nutrition, NCDs } \\
\text { and urban food } \\
\text { insecurity }\end{array}$ \\
\hline $\begin{array}{l}\text { Economic growth } \\
\text { policies: Improving } \\
\text { nutrient affordability } \\
\text { through the creation } \\
\text { of new economic } \\
\text { opportunities for } \\
\text { catch-up growth }\end{array}$ & $\begin{array}{l}\text { Policies for a Green } \\
\text { Revolution } 2.0\end{array}$ & $\begin{array}{l}\text { Diversification to } \\
\text { the non-agricultural } \\
\text { sectors }\end{array}$ & $\begin{array}{l}\text { Policies for planned } \\
\text { urban development } \\
\text { and growth }\end{array}$ \\
\hline
\end{tabular}

simultaneously enact policies which aim at reducing obesity while addressing the issue of urban food insecurity. Our policy recommendations aim at allowing states to choose policies which address their unique nutritional and agricultural challenge while factoring in their state of structural transformation. The end goal of our policies would be to facilitate to states to move into a structural transformation pathway which addresses the context-specific development challenge while ensuring high growth. In this context, agricultural and economic growth policies grounded in critical regional concerns for nutrition are the key to ensuring greater nutrition security and rural prosperity.

In the past, in recognition of the role of state in facilitating its own development, the Indian constitution allotted the subjects of agriculture, health and industries to states and concurrent subjects, respectively. For all substantive development issues, the state government was envisioned to be the main implementation agency of policy while the central government was assumed to support in funding and providing technical support. Due to the scarcity of resources and a low savings rate after independence from 
the British, the central government had to play the leadership role in both aggregating fiscal resources nationally as well as in designing and implementing development programs with critical national security concerns. However, over time, we have seen that this approach has led to an inadvertent divergence in economic development across states. States which have been most successful in structural transformation have reduced their dependence on the central government for fiscal transfers and have implemented their own state run initiatives for tackling the most pressing development concerns. This has facilitated greater structural transformation in these regions. Thus, in our approach, we advocate for the greater decentralization of resources to state governments and greater flexibility in designing and implementing policies that best tackle their unique development challenges while also facilitating greater growth based on their comparative advantages. In our model, for example, the central government plays the role of a coordinator in the development process. It is responsible for setting national goals, monitoring progress towards these goals, bolstering financing of the various interventions and programs and creating synergies across the various stakeholders including the private sector, the federal government and the farmers. In its new role, the central government would improve coordination across departments which oversee the development of economic sectors as well as reduce inefficiencies in implementation. The primary role for the central government would be to invest in research and development to improve the quality of services provided and increase access to technology for use in human capital production. To encourage innovation, increase efficiency and increase the capacity to scale initiatives, greater private sector participation needs to be encouraged as well.

\subsection{Policies for Agricultural Development: Facilitating Greater Nutrient Availability and Rural Prosperity Through Commercialization AND DIVERSIFICATION}

The key to success for the agricultural sector in general and farmers specifically lies in commercialization and diversification. There exists a tremendous opportunity for farmers in catering to the rising urban demand for higher value agricultural products (T. Reardon \& Timmer, 2007). Diversification of production not only improves the availability and access of nutritious 
food for the consumers but also provides a greater capacity for the farmers to grow out of poverty and share in the benefits of economic growth (Pingali \& Rosegrant, 1995). Diversification of the agricultural sector however fundamentally hinges on the ability of smallholders - which make up the majority of Indian farmers - to overcome constraints to accessing input and product markets and increase production efficiency. Smallholders often face disadvantages in accessing input markets such as credit, quality seeds, fertilizer, pesticides, farm machinery and R\&D to diversify and generate a marketable surplus (Abraham \& Pingali, 2017). They also lack access to output markets to sell their produce at fair prices. In the absence of commercialization in lagging regions, smallholders continue to practice low risk, low return production of basic staple grains. Traditionally smallholder production had the advantage of higher labor utilization and low monitoring costs through the utilization of family labor. In recent years, increasing non-farm wages have led to a rise in seasonal migration, which has led to reduced utilization of family labor. Additionally, poor economies of scale limit the scope and ability of smallholders for mechanizing or adopting new technologies and linking to urban value chains. These factors have contributed to declining farm productivity, especially in the lagging states.

The role of climate change in agricultural production is another major challenge for smallholder production. In the past two decades, the increasing uncertainties from changing weather patterns and resource degradation from the overuse of land and water have emerged to be additional concerns. Addressing these will be necessary for policies focused on agricultural growth in the future. In this section, we look at the interventions needed to rectify smallholder disadvantages for commercialization and improved access to technology and sustainable intensification, making agriculture climate-smart and effectively managing value chains to improve efficiency and reduce wastage.

\subsubsection{Promoting Aggregation Models and Rectifying Smallbolder Disadvantages of Scale}

Institutional interventions can offset scale disadvantages faced by small farms and enable improved agricultural production. By reducing the risk associated with the adoption of new crop technologies and reducing transaction costs in market access, these interventions could help in farm diversification as well as in achieving better price realizations in the output market. Aggregation models such as FPOs and cooperatives are 
examples of these types of interventions. At the farm level, aggregation helps smallholders to access credit and other inputs at a more competitive cost. Access to extension services is also increased through these models at very low costs. Joint marketing of produce opens up avenues for vertical coordination (VC), access to electronic markets, trading in commodity futures and benefit from warehousing platforms.

In Table 11.2, we highlight some recommendations that differ by the type of regional development. In the lagging states with low agricultural productivity, FPOs have the potential to enable greater commercialization, enabling greater yields. Linkages to output markets will help incentivize the production of pulses and coarse grains, given their comparative advantage. In agriculture-led states and urbanizing states, alternative models such as contract farming are more likely to succeed since they already have higher yields. Enabling conditions for contract farming through mechanisms to enforce contracts and allowing retailers and processors to transact directly with farmers, especially in the cash crops, could be the way forward. Here, aggregation models can help reduce organization costs of engaging with a more significant number of small farms and reduce contracting costs that often exclude small farm contracts. Policy measures to financially support FPO emergence, extend financial and insurance-based services, link them to information and extension services and enable market linkages by improving connectivity will further incentivize group formation and establish linkages across the value chain.

\subsubsection{Reforming Markets to Improve Farmer Participation and Increase the Efficiency of Transactions}

Traditional markets or mandis are the main platforms for agricultural marketing. In lagging states, the primary challenge for smallholders is access to traditional markets. With small surplus produce, large distances to markets and poor rural connectivity, market participation is lower. Intermediaries benefit from the missing market and expropriate a large part of the smallholders' profit. Improving connectivity and infrastructure, therefore, is critical. Farmers also find it difficult to sell in the markets without appropriate grading and standardization of their produce. Establishing systems of grades and standards determination, checks on malpractices in weighing at the mandis, and information on prices further encourage market participation. These measures are vital for developing agricultural marketing systems to stimulate greater agriculture-related development in lagging states. 
Table 11.2 Policies for enabling diversification and commercialization of farm systems

\begin{tabular}{|c|c|c|c|}
\hline $\begin{array}{l}\text { Agricultural } \\
\text { sector }\end{array}$ & Lagging states & Agriculture-led states & Urbanizing states \\
\hline $\begin{array}{l}\text { Promoting } \\
\text { aggregation } \\
\text { models and } \\
\text { rectifying } \\
\text { smallholder } \\
\text { disadvantages of } \\
\text { scale }\end{array}$ & $\begin{array}{l}\text { Promoting FPOs } \\
\text { and cooperatives to } \\
\text { rectify smallholder } \\
\text { farmer } \\
\text { disadvantages in } \\
\text { accessing input and } \\
\text { output markets }\end{array}$ & $\begin{array}{l}\text { Linking farms to } \\
\text { markets through } \\
\text { contract farming. FPOs } \\
\text { enforcing contracts and } \\
\text { monitoring and } \\
\text { evaluations }\end{array}$ & $\begin{array}{l}\text { Creating opportunities } \\
\text { for contract } \\
\text { enforcement, direct } \\
\text { procurement etc. for } \\
\text { export-oriented } \\
\text { production in cash } \\
\text { crops }\end{array}$ \\
\hline $\begin{array}{l}\text { Reforming } \\
\text { markets to } \\
\text { improve } \\
\text { participation and } \\
\text { efficiency }\end{array}$ & $\begin{array}{l}\text { Improving } \\
\text { connectivity and } \\
\text { marketing } \\
\text { infrastructure }\end{array}$ & $\begin{array}{l}\text { Enabling vertical } \\
\text { coordination models }\end{array}$ & $\begin{array}{l}\text { Promoting alternative } \\
\text { platforms-E-trading, } \\
\text { commodity futures and } \\
\text { direct procurement for } \\
\text { retail sectors }\end{array}$ \\
\hline $\begin{array}{l}\text { Increasing access } \\
\text { to technology } \\
\text { adoption for } \\
\text { sustainable } \\
\text { intensification }\end{array}$ & $\begin{array}{l}\text { HYV in coarse grain } \\
\text { and pulses, adopting } \\
\text { other high-value } \\
\text { crops and foods }\end{array}$ & $\begin{array}{l}\text { Diversification out of } \\
\text { staple grains towards } \\
\text { high-value agriculture } \\
\text { (fruits, vegetables, } \\
\text { livestock) }\end{array}$ & $\begin{array}{l}\text { Integrating ICT into } \\
\text { agricultural systems, } \\
\text { precision farming, to } \\
\text { conserve natural } \\
\text { resources }\end{array}$ \\
\hline $\begin{array}{l}\text { Making } \\
\text { agriculture } \\
\text { production } \\
\text { systems } \\
\text { climate-smart }\end{array}$ & $\begin{array}{l}\text { Drought, heat, } \\
\text { flood, disease- } \\
\text { resistant } \\
\text { technologies for } \\
\text { crops, irrigation } \\
\text { infrastructure and } \\
\text { natural resource } \\
\text { management groups }\end{array}$ & $\begin{array}{l}\text { Sustainable } \\
\text { intensification of } \\
\text { agricultural systems, } \\
\text { reducing land } \\
\text { degradation through } \\
\text { input management }\end{array}$ & $\begin{array}{l}\text { Drought, heat, flood, } \\
\text { disease-resistant } \\
\text { technologies for crops, } \\
\text { irrigation infrastructure } \\
\text { and natural resource } \\
\text { management groups }\end{array}$ \\
\hline $\begin{array}{l}\text { Increasing } \\
\text { bio-availability of } \\
\text { nutrients in the } \\
\text { food supply } \\
\text { chains }\end{array}$ & $\begin{array}{l}\text { Increasing farm } \\
\text { diversification and } \\
\text { development of } \\
\text { non-staple } \\
\text { production systems }\end{array}$ & $\begin{array}{l}\text { Increasing bio- } \\
\text { availability of } \\
\text { micronutrients in staple } \\
\text { crops, creating } \\
\text { fortification industries } \\
\text { for processed foods, } \\
\text { increasing demand for } \\
\text { micronutrient-rich foods }\end{array}$ & $\begin{array}{l}\text { Creating urban markets } \\
\text { for bio-fortified crops, } \\
\text { organic foods and } \\
\text { foods rich in } \\
\text { micronutrients, } \\
\text { reducing food loss and } \\
\text { waste through supply } \\
\text { chain interventions }\end{array}$ \\
\hline
\end{tabular}

With changing demand for quality and high-value agricultural produce, alternative value chains and newer marketing platforms have emerged. Vertical coordination (VC) by which retailers form direct linkages with farms and bypass traditional markets has been growing in agriculture-led growth states and urbanizing states. Newer marketing platforms where farmers can participate in online auctions and trading such as eNAM and 
Rashtriya e-Market Services Pvt. Ltd. (ReMS) in Karnataka and warehousing platforms such as the National Commodity \& Derivatives Exchange (NCDEX) eMarkets Limited can be viable alternatives to existing traditional markets (Reddy, 2016). VC can be more relevant for perishable crops and farmers in regions with good linkages to market (agriculture-led growth states) while futures and warehousing platforms can be useful for nonperishable commodities and can emerge in low potential areas such as those in lagging states. Different marketing arrangements can help serve specific purposes of farms, conditioned on geographical and crop characteristics.

\subsubsection{Increasing Access to Technology Adoption for Sustainable Intensification}

Technology has played a critical role in enabling food security in the developing world. The Green Revolution (GR) helped in increasing yields of wheat and rice, making many countries like India self-sufficient in these grains. GR technologies were conventional plant-breeding (CPB) technologies that were limited to wheat and rice in the context of India. Additionally, implementation of GR technologies was limited to regions with access to irrigation and (or) consistent rainfall. This led to interregional disparities in agricultural development where states with comparative advantages in staple crop production benefited disproportionately in comparison to other states. Another fallout of these technologies was their impact on the environment. Because of poor management of natural resources and overuse of subsidized inputs such as fertilizers and pesticides, the Green Revolution has also resulted in depletion of water tables and the degradation of land and soil quality. The role of technology in the wake of new production challenges for diversifying food systems in the presence of climate change and environmental degradation is thus to increase yields while reducing environmental externalities through sustainable intensification.

New agricultural technologies have gone beyond conventional plantbreeding technologies of the Green Revolution to the genetically modified organisms (GMOs). The first generation of genetically modified (GM) crops have traits that give them tolerance or resistance to insects, pesticides and herbicides. In India, Bt cotton, which has an inbuilt resistance to boring pests, is the only first-generation GMO that was introduced to the agricultural sector. Second-generation GMOs are crops engineered to 
have increased tolerance to abiotic stress (drought, flood salinity) and increased nutrient (protein, amino acids, fatty acids, starch, vitamins, minerals and enzymes) content, enabling the creation of resilient and more nutritive crops (Buiatti, Christou, \& Pastore, 2013; Flachowsky \& Aulrich, 2001; C. N. Rao, Pray, \& Herring, 2018). Both first- and secondgeneration GM technologies will prove to be critical in the wake of the food systems challenges India is facing. In lagging states, agriculture-led states and urbanizing states, GMOs can help in the reduction of climaterelated risks through heat and drought resistance crops, and they can increase yield and reduce the cost of production in crops through built-in pest resistance. So far, no GMOs except Bt cotton have been allowed in the Indian agricultural sector. There has been much debate about the safety of GM crops in India and around the world. Despite no evidence being found that GMOs are detrimental to human, animal and environmental health, there has been much opposition to it, discouraging investments and innovation in agricultural $R \& D$. India needs to have more forward-looking bio-technology policies and institutions that can allow the introduction of these new technologies into the agricultural sector. This is essential to bolster innovation and investment from the private sector and enable institutional support for the adoption of biotechnology in agriculture.

\subsubsection{Making Agriculture Production Systems Climate-Smart}

Given the close relationship between poverty, agriculture production and weather, developing adaptation strategies to protect smallholders from climatic risks is essential. Climate-smart agriculture (CSA) to ensure enhanced productivity, increased resilience and limited environmental externalities require a combination of technology, management practices, infrastructure and information systems that can help mitigate, reduce or withstand the effects of climate change (Lipper et al., 2014). The core elements needed for the transition to CSA are: (a) information, evidence gathering and assessment, (b) strengthening of national and local institutions, (c) evidence-based policy making and (d) financing transition (ibid). The accessibility and availability of information are crucial to making proper planting, harvesting and marketing decisions needed for agricultural growth and development. Information communication technologies (ICTs) have shown to have great potential in reducing information asymmetries and improving the efficiency of production and marketing (Aker \& Fafchamps, 2015; Fischer, Byerlee, \& Edmeades, 2009; 
S. Mittal \& Mehar, 2012). ICTs often rely on platforms on which information can be collated, analyzed and disseminated. These platforms need to be put in place to bring together context-specific information regarding weather, technical extension and markets.

Evidence-based policy making is central to the implementation of CSA, especially about biotechnology policies to enable technology adoption. Second-generation GMO crops that are heat, drought and flood resistant can play a role in reducing crop failure and improving nutrient content in plants that will be affected through climate change (C. N. Rao et al., 2018). Policy to allow the introduction of GM crops will help reduce climate-related risks and cost of production and also increase the bioavailability of nutrients that can potentially be lost due to global warming. Management of resources that goes into agricultural production needs to complement technology adoption for sustainable intensification and reduced environmental externalities. Removal of input subsidies for electricity and fertilizers is important, as these measures in the past have led to overuse of groundwater and over-application of nitrogenous fertilizers. Supplementing agricultural programs with agroforestry for carbon sequestering, soil conservation and watershed management initiatives is essential for replenishment of common-pool resources used for agricultural production. Institutional strengthening through community-based collective actions is needed to enable conservation programs. Empowering aggregation models to take up the task of common-pool resource management will reduce the cost of organization and incentivize cooperation aligned with primary economic activities. Supporting adoption of CSA and transitioning from conventional agriculture requires financing and credit support. The role of the government and policies to improve access to financial services and build infrastructure is going to be critical.

\subsubsection{Increasing Bio-availability of Quality Nutrients in the Food Supply Chain}

Modernizing supply chains is essential to reduce loss and waste and ensuring greater food and nutrient availability in the food systems. Infrastructure investments in connecting farms to markets through the construction of good quality roads, developing infrastructure in cold chains and warehouses to reduce spoilage and creating testing facilities to establish grades and standards will be important steps towards this goal. Given the experience of other developing nations and emerging economies, encouraging 
the participation of the private sector and sustainability-oriented businesses to increase efficiency along the supply chain is one possible channel to facilitate this transition.

Climate change poses a major threat to agricultural production and nutrient availability in the future (Myers et al., 2014). Rising temperatures during the growing season have been found to reduce nutrient availability in plants and reduce yields of crops (P. K. Aggarwal \& Mall, 2002; Lobell, Schlenker, \& Costa-Roberts, 2011; Schlenker \& Roberts, 2009). Increasing access to good quality nutrition requires interventions that tackle this problem at multiple levels. First, improving soil quality through crop management will be important to ensure greater nutrient availability in crops. Policies that encourage diversity in production reduce dependence on rain water and research on the application of nutrients based on real time soil quality will be important. Agroforestry initiatives supported by the appropriate decentralization of common property rights have been found to be effective in enabling conservation practices such as watershed management (R. R. Banerjee, 2015; Gross-Camp, Few, \& Martin, 2015; Myers et al., 2017; Sinha \& Swaminathan, 1992; Steiner, Briske, Brown, \& Rottler, 2018). Second, encouraging research on improving the bioavailability of nutrients in crops will also be required going forward. Currently, research and development still focus on biofortification of staple crops since staples constitute a large portion of most individuals' dietary requirements (Meenakshi et al., 2010; Qaim, Stein, \& Meenakshi, 2007). Moving forward, fortification of non-staples, increasing micronutrient availability through current food safety net programs and climate technology to prevent micronutrient loss from crops due to erratic weather conditions will need to become part of the Indian agriculture and food policy innovations. Third, a more innovative approach is to create new markets for nutrition that can properly signal the value of nutrition and health in foods, especially in urbanizing states (Costa-Font, Gil, \& Traill, 2008). This would create a demand pull for growing more nutritious crops, thus encouraging research and development into the same. For this to happen, developing food safety standards, the demand for organic products and demand for other nutritious non-staple foods through education will be important. Fourth, investments in improving nutrition content of food through fortification of processed foods will play an important role in increasing micronutrient availability in diets (Pinstrup-Andersen, 2009). Incentivizing private sector participation in developing and marketing bio-fortified foods will be important in this context. 


\subsection{Policies for the Nutrition Transition: Increasing Access to Good Quality Foods AND NuTRIENTS}

In India, undernutrition and micronutrient deficiency simultaneously coexist with the phenomenon of rising obesity, leading to the triple burden of malnutrition. In Chap. 5, we described the multitude of pathways influencing malnutrition and the nutrition challenges different regions are faced with. In lagging states, the main goal for improving nutrition would be to reduce hunger and diet-related undernutrition in addition to micronutrient deficiencies among children. For agriculture-led states and urbanizing states, the main challenge would be tackling obesity and micronutrient deficiencies in both children and adults. For urbanizing states, in addition to reducing obesity, the policy focus needs to be on creating safety nets for reducing urban food insecurity, especially around food access because poor urban residents completely rely on purchased food (Maitra \& Rao, 2015). As the nature of nutrition challenges varies across regions, a regional approach to tackle the specific problem of malnutrition should be the way forward. In Table 11.3, we provide a summary of how policies could be tailored to reduce region-specific malnutrition.

\subsubsection{Intra-Household Safety Nets to Improve Nutrient Access for Women and Children}

Even when healthy foods are available within the household, intrahousehold distribution of access to quality and quantity of nutritious foods could be different by age and gender. In countries such as Mexico and Brazil, cash transfers and conditional cash transfer (CCT) programs have been found to have positive impacts on overcoming intra-household level dynamics that reduce nutrition access. Targeting conditional cash transfers to girls in households increases their access to nutrition in addition to increasing educational outcomes (Attanasio, Gomex, Heredia, \& Verahernández, 2005; Behrman, Parker, \& Todd, 2011; Handa \& Davis, 2006; Leroy, Ruel, \& Verhofstadt, 2009). These CCTs are also effective in preventing the worsening of nutrition outcomes of girl children when households undergo health-related or income-related shocks (Attanasio et al., 2005; Fernald, Gertler, \& Neufeld, 2008). In agriculture-led growth states where women's empowerment is low and incomes are relatively high, implementing labor market reforms to increase women's labor force 
Table 11.3 Policies for reducing the triple burden of malnutrition

\begin{tabular}{|c|c|c|c|}
\hline $\begin{array}{l}\text { Health and } \\
\text { nutrition }\end{array}$ & Lagging states & Agriculture-led states & Urbanizing states \\
\hline $\begin{array}{l}\text { Implementing } \\
\text { intra-household } \\
\text { safety nets to } \\
\text { improve nutrition } \\
\text { access for women } \\
\text { and children }\end{array}$ & $\begin{array}{l}\text { Conditional cash } \\
\text { transfers to } \\
\text { encourage women to } \\
\text { purchase nutritious } \\
\text { foods, increasing } \\
\text { women's access to } \\
\text { the ICDS and } \\
\text { MDMS }\end{array}$ & $\begin{array}{l}\text { Conditional cash } \\
\text { transfers consumption } \\
\text { to encourage women } \\
\text { to purchase nutritious } \\
\text { foods, increasing } \\
\text { women's access to } \\
\text { the ICDS and } \\
\text { MDMS }\end{array}$ & $\begin{array}{l}\text { Unconditional cash } \\
\text { transfers and CCTs to } \\
\text { ensure that women } \\
\text { can access diverse } \\
\text { foods from markets, } \\
\text { increasing women's } \\
\text { access to the ICDS } \\
\text { and MDMS }\end{array}$ \\
\hline $\begin{array}{l}\text { Investing in } \\
\text { health-related } \\
\text { infrastructure such } \\
\text { as water, sanitation }\end{array}$ & $\begin{array}{l}\text { Improving water } \\
\text { quality, building } \\
\text { toilets, interventions } \\
\text { for reducing new } \\
\text { diseases that climate } \\
\text { change may bring }\end{array}$ & $\begin{array}{l}\text { Improving water } \\
\text { quality, building and } \\
\text { encouraging toilet } \\
\text { use, interventions for } \\
\text { reducing mosquitoes } \\
\text { and pests from } \\
\text { climate, }\end{array}$ & $\begin{array}{l}\text { Increasing urban } \\
\text { water availability, } \\
\text { building and } \\
\text { encouraging toilet } \\
\text { use, interventions for } \\
\text { reducing mosquitoes } \\
\text { and pests from } \\
\text { climate, }\end{array}$ \\
\hline $\begin{array}{l}\text { Encouraging } \\
\text { behavior change } \\
\text { towards more } \\
\text { healthy nutrition } \\
\text { consumption } \\
\text { practices }\end{array}$ & $\begin{array}{l}\text { Taxes on unhealthy } \\
\text { foods, promoting } \\
\text { organic foods, } \\
\text { encouraging hand } \\
\text { washing and proper } \\
\text { sanitation practices, } \\
\text { along with BCC on } \\
\text { nutrition } \\
\text { consumption }\end{array}$ & $\begin{array}{l}\text { State focused: } \\
\text { Behavior change } \\
\text { (reduction in } \\
\text { obesity), taxes on } \\
\text { unhealthy foods, } \\
\text { promoting organic } \\
\text { foods, food labeling, } \\
\text { grades and standards, } \\
\text { with BCC on } \\
\text { nutrition }\end{array}$ & $\begin{array}{l}\text { Urban focused: } \\
\text { Behavior change } \\
\text { (reduction in obesity), } \\
\text { taxes on unhealthy } \\
\text { foods, promoting } \\
\text { organic foods, food } \\
\text { labeling, grades and } \\
\text { standards }\end{array}$ \\
\hline $\begin{array}{l}\text { Increasing health } \\
\text { service capacity } \\
\text { and improving the } \\
\text { quality of care }\end{array}$ & $\begin{array}{l}\text { CDs: Vaccines usage } \\
\text { promotion, health } \\
\text { insurance (reducing } \\
\text { burden for children) }\end{array}$ & $\begin{array}{l}\text { NCDs: Health } \\
\text { insurance, tertiary } \\
\text { hospitals (reducing } \\
\text { burden for adults) }\end{array}$ & $\begin{array}{l}\text { NCDs: Health } \\
\text { insurance, tertiary } \\
\text { hospitals (reducing } \\
\text { burden for adults) }\end{array}$ \\
\hline $\begin{array}{l}\text { Bolstering other } \\
\text { safety nets to } \\
\text { address urban } \\
\text { food security and } \\
\text { improve access to } \\
\text { nutrients }\end{array}$ & $\begin{array}{l}\text { Procuring and } \\
\text { distributing } \\
\text { non-staples, } \\
\text { bio-fortified crops } \\
\text { and fortified foods } \\
\text { through the PDS, } \\
\text { universal health } \\
\text { insurance }\end{array}$ & $\begin{array}{l}\text { Health insurance } \\
\text { programs to improve } \\
\text { access to care, } \\
\text { improving quality of } \\
\text { the urban PDS }\end{array}$ & $\begin{array}{l}\text { Health insurance } \\
\text { programs to improve } \\
\text { access to care, } \\
\text { improving quality of } \\
\text { the urban PDS }\end{array}$ \\
\hline
\end{tabular}


participation and increasing women's remuneration along with CCTs could be important interventions. The effectiveness of these interventions lies in redefining the roles of women as active income-generating members within households. In urbanizing states, reforms in the labor markets to increase women's engagement in the labor markets and unconditional cash transfers to women will be essential interventions. Since women are relatively more empowered in these states, these changes will further increase the bargaining power of women both at home and in the workplace, thus improving child health outcomes (E. Kennedy \& Peters, 1992). In lagging states, a combination of CCTs and in-kind transfers will remain important. In-kind food transfers through the ICDS and the MDMS programs have been found to be effective in improving nutrition outcomes within households, but they require better monitoring and effective governance in the lagging states (Anjana et al., 2015; Khera, 2006; P. Pingali, Mittra, \& Rahman, 2016). Finally, interventions that increase the education of girl children and women, delay child marriages, provide households information on economic opportunities for women and increase safety at workplaces have been known to impact both nutrition outcomes for women and their children (R. Jensen, 2010, 2012). Improving labor conditions, investing in schools, and educating parents on investing in their girl children will thus have to remain priorities for intra-household safety net development.

\subsubsection{Water and Sanitation Infrastructure for Better Health Outcomes}

Poor hygiene environments increase disease burden and sickness and affect nutrient absorption. Improving water and sanitation infrastructure are essential to reduce the spread of disease, especially waterborne diseases (Mengistie, Berhane, \& Worku, 2013). Infrastructure provisions for clean water and sanitation facilities also require behavior change. Unless there is a change in beliefs within households about cleanliness related to toilet use, individuals tend to avoid the use of the constructed toilet, thus defeating the purpose of improving the health environment (Spears, Ghosh, \& Cumming, 2013). Behavior change programs that seek to improve the household health environment by encouraging water storage practices, encouraging hand washing before water use and after toilet use, and 
encouraging cleanliness in the surrounding environment have been effective in reducing malnutrition around the world (Biran et al., 2008, 2014; Lee, Rosenzweig, \& Pitt, 1997; Mangyo, 2008; J. H. Rah et al., 2015). There are currently experimental trials being conducted in rural villages in India to identify the constraints and challenges for households in adopting these practices.

Looking into the future, rapid urbanization of states increases the need to invest in water and sanitation infrastructure required to improve urban food and nutrition security. This is a pressing concern in major cities where higher population density and the existence of slums-with little or no sanitation facilities - increase household vulnerability to air or waterborne communicable diseases. Climate change further threatens to worsen the potency of diseases in urban areas where water and sanitation infrastructure are inadequate. Without proper urban development strategies that incorporate both food and nutrition policies into development, the human costs of urban growth may outweigh its benefits.

\subsubsection{Encouraging Behavior Change Towards More Healthy Nutrition Consumption Practices}

With changing incomes and lifestyles, over-nutrition that manifests as obesity is an emerging health-related concern, especially in urban areas and among women. Greater obesity is correlated with lower productivity, health and wages of individuals and hence this phenomenon should be of increasing concern (Cawley, 2004, 2010; Cawley \& Meyerhoefer, 2012; Thow et al., 2018). Greater consumption of processed food and a sedentary lifestyle can be attributed to this emerging phenomenon in urban areas. To combat the problem, behavior change communications and nutrition education could be used to nudge individuals towards healthy eating habits. Policy instruments such as taxes on unhealthy sugary foods, like in Mexico, could be useful to reduce consumption of the same (Cawley, 2015; M. A. Colchero, Salgado, Unar-Munguia, HernandezAvila, \& Rivera-Dommarco, 2015; M. A. Colchero, Rivera-Dommarco, Popkin, \& Ng, 2017). Other interventions such as nutrient labeling, the introduction of food safety standards as well as the certification of organic and healthy foods have been found to increase consumer demand for such products (Padel \& Foster, 2005). Publishing scientific research on the nutrition content of foods and its effects on health has also played an 
essential role in increasing public awareness of consuming balanced diets. These factors can play a significant role in increasing household diet diversity as well as reducing obesity.

Tackling undernutrition within households through education interventions requires understanding the information gap and the intrahousehold dynamics that impact nutrition access. Information campaigns on the importance of breastfeeding, the importance of eating healthy and adopting healthy nutrition practices within households, the importance of consuming micronutrients in diets and so on could be the essential interventions to improve nutrition consumption within households. Research has shown that when women are empowered to make decisions with regard to these household goods, the health of the household improves (Bennett, 1988). However, it is often the case that decisions are taken either by the male members or women in positions of power. Thus involving these men and mother in laws in these behavior change campaigns while discussing women's empowerment is also crucial in ensuring greater access to nutrition within the household's threshold.

\subsubsection{Increasing Health Service Capacity and Improving the Quality of Cave}

A major health threat is the rising incidence of non-communicable diseases (NCDs). NCDs such as heart disease, diabetes and some cancers, if diagnosed early, can be treated and managed. The onset of these diseases requires palliative care and lifestyle changes to manage these conditions. Thus, managing the problem of NCDs that are specific to India requires investment in research and development into preventive care, palliative care and development of diagnostic practices and treatment protocols. Sales taxes collected from unhealthy food consumption or tobacco and alcohol use can be useful in raising resources to help build such systems. These public policy tools are also known to encourage more health behaviors in individuals. Additionally, interventions that increase quality of health services provided through the public health systems, building capacity of health service providers and regulating discriminatory private health services practices will be important in ensuring the health system remains fair and equitable for those who access it.

Climate change has been associated with changing the potency of communicable diseases within locations as well as with the growth of new 
disease burdens in locations that were previously not susceptible to the same. In areas where water and sanitation are poor and climatic shocks threaten infrastructure services, changes to the health environment are expected to further derail progress made towards tackling communicable diseases. Thus in addition to implementing appropriate interventions that increase the quality of water and sanitation infrastructure, climate change mitigation and adaptation strategies that involve the development of vaccines and treatment protocols for treating communicable diseases are also required. Children in lagging states would be most vulnerable due to their lack of access to good quality healthcare services. In such situations, implementing epidemiological disease monitoring units in addition to interventions to provide timely care in the event of disease outbreak will be extremely important for reducing malnutrition. In more developed states, integrating monitoring technology with health services provisions will be essential inputs into controlling the spread of communicable diseases as well. However, cost effective interventions need greater flexibility built into the process of preventative care and treatment. For example, each state needs to be equipped with funds and technology that will best help them tackle the communicable disease with the highest disease burden.

\subsubsection{Bolstering Safety Nets to Address Urban Food Security and Improve Access to Nutrients Beyond Calories}

A robust safety net architecture has emerged in India over the last two decades (Drèze \& Khera, 2017). It is a welcome change given the rising inter-personal inequality and improved fiscal capacity of the government. The policy challenge lies in the issue of the direction and design of these initiatives. The existing social protection paradigm is structured around the idea of reducing poverty and vulnerability. While this will continue to be an essential idea behind safety nets, a futuristic policy should also consider thinking about designing programs which reduce the likelihood of people falling into poverty. Social support for the poor is palliative or curative, preventive policies like insurance programs could be a new policy direction. Efficacy of such policies is also bolstered by the fact that economic shocks, like health and weather, are one of the major causes of households falling into poverty in India. Rising informal employment, where income is highly variable, has been a significant concern of late 
across many countries. Social protection, therefore, of various kinds, with various objectives, provide a safety net to the disadvantaged.

The design of safety net programs also needs to be linked to the changing nature of structural transformation (Croppenstedt, Knowles, \& Lowder, 2017). Much of these policies currently focus on the rural areas. By 2050, India is expected to be more urban, even by the most conservative official figures. Concerns of "urbanization of poverty" have already begun to dominate scholarly debates and news headlines (Ravallion, 2002). Combined with a large share of informal urban employment structure, unhygienic living conditions, especially for the poor, make the urban food systems susceptible to malnutrition. Being net consumers of food, urban food systems are more susceptible to food price fluctuations \& thus greater food insecurity during climate change events. Urbanization and NCDs have a clear association as well. In these contexts, NCDs are likely to rise faster in poorer communities-as is happening in middle- and higher-income countries (Bollyky, Templin, Cohen, \& Dieleman, 2017). The role of safety nets in urban areas, therefore, will be of critical importance as India grows. The issue of labor mobility and reduced quality of life of migrants further adds to the clarion call for a robust urban safety net program (Gentilini, 2015). Debates around introducing UBI and the importance of cash transfers will therefore be a welcome addition to urban safety net discussions. In urban areas, where banking infrastructure is well-developed, cash transfers can be effective in increasing households ability to purchase diverse food. In lagging states, market development needs to precede a move to cash transfers. UBI, while in its inception, shall progressively become a useful social assistance program.

Health insurance schemes are definitely a welcome addition in reducing the likelihood of poverty and mortality. More developed states in south India have done well on the take-up of government health insurance programs while the underdeveloped regions have fared poorly. Greater financial literacy among the population and well-developed insurance markets should precede these interventions in order to increase its effectiveness. Also, interventions for crop or livestock insurance should be introduced as they improve the ability of smallholders to adopt new technologies and hedge risks against climate related shocks. Collectively, these risk-absorbing interventions enhance households' abilities to tide over production \& consumption shocks, thus increasing household food security and reducing their risk of malnutrition. 


\subsection{Policies for ECONOMic Development: Creating Economic Opportunities for Catch-Up Growth and Linking Food Systems to the Job Agenda}

We have argued throughout the book that economic development patterns are varied across different Indian states. Urbanizing states have been able to leverage their comparative advantages and grow with the local and global economy. The agriculture-led growth states reaped the benefits of the Green Revolution and hence reduced poverty and malnutrition successfully. The lagging states, however, need to catch up in order to stay competitive. Aligning agricultural development to overall economic growth is essential to ensure equitable and sustainable development in these areas. In lagging states, the main goals will be to ensure the development of rural infrastructure, stimulate non-farm growth and reduce labor market frictions to enable better labor utilization in the economy. Dovetailed with equitable growth strategies is the importance of sustainable growth policies. Climate change has had a significant impact on all sectors of the economy and measures to mitigate its effects will require climate-smart interventions in all sectors. In agriculture-led states and urbanizing states, institutional interventions to ensure good governance (especially urban and peri-urban areas), creating the climate for sustainability-oriented investments and interventions, encouraging private sector participation and creating an environment for technological innovation will help in sustaining economic and agricultural growth. In this section (see Table 11.4 for an overview), we discuss policies that can facilitate opportunities for economic growth based on patterns of development with the intention of creating institutions to encourage climate-smart investments and boost private sector participation.

\subsubsection{Improving Rural Infrastructure to Stimulate Non-farm Growth and Improve Connectivity to Urban Areas to Stimulate Rural Development}

Diversification of rural livelihood sources is a critical household strategy to hedge income security risks associated with agricultural production and increase food security (Ellis, 1998). As countries structurally transform and labor transitions out of the agricultural sector, household income sources from the non-farm sector also grow (Timmer, 1988). In India, a majority of rural households have a mix of farm and non-farm income 
Table 11.4 Policies for creating economic opportunities for catch-up growth

\begin{tabular}{|c|c|c|c|}
\hline $\begin{array}{l}\text { Economic growth } \\
\text { and development }\end{array}$ & Lagging states & Agriculture-led states & Urbanizing states \\
\hline $\begin{array}{l}\text { Improving rural } \\
\text { infrastructure and } \\
\text { connectivity to } \\
\text { urban areas }\end{array}$ & $\begin{array}{l}\text { Investing in roads, } \\
\text { power, irrigation, } \\
\text { supply chains etc. } \\
\text { focused on rural } \\
\text { development }\end{array}$ & $\begin{array}{l}\text { Upstream supply } \\
\text { chain linkages to } \\
\text { agriculture }\end{array}$ & $\begin{array}{l}\text { Downstream supply } \\
\text { chain linkages to } \\
\text { agriculture }\end{array}$ \\
\hline $\begin{array}{l}\text { Reducing labor } \\
\text { market frictions that } \\
\text { prevent the flow of } \\
\text { underemployed } \\
\text { labor towards more } \\
\text { productive } \\
\text { economic } \\
\text { opportunities }\end{array}$ & $\begin{array}{l}\text { Women's safety, } \\
\text { education of the } \\
\text { labor force, creating } \\
\text { rural employment } \\
\text { exchanges, upskilling } \\
\text { the labor force }\end{array}$ & $\begin{array}{l}\text { Women's safety, } \\
\text { education of the } \\
\text { labor force, creating } \\
\text { urban unemployment } \\
\text { insurance, rural } \\
\text { employment } \\
\text { exchanges, reskilling } \\
\text { the labor force for } \\
\text { the non-agricultural } \\
\text { sector }\end{array}$ & $\begin{array}{l}\text { Women's safety, } \\
\text { education of the } \\
\text { labor force, urban } \\
\text { unemployment } \\
\text { insurance, urban } \\
\text { employment } \\
\text { exchanges, reskilling } \\
\text { the labor force } \\
\text { towards high-skilled } \\
\text { jobs }\end{array}$ \\
\hline $\begin{array}{l}\text { Improving the } \\
\text { capacity of urban } \\
\text { governance bodies } \\
\text { to facilitate urban } \\
\text { development and } \\
\text { climate proof major } \\
\text { cities }\end{array}$ & $\begin{array}{l}\text { Improving } \\
\text { governance systems } \\
\text { for small towns, } \\
\text { investing in drinking } \\
\text { water, infrastructure, } \\
\text { migration, resource } \\
\text { use etc. }\end{array}$ & $\begin{array}{l}\text { Improving } \\
\text { governance systems } \\
\text { for small towns, } \\
\text { investing in drinking } \\
\text { water, infrastructure, } \\
\text { migration, resource } \\
\text { use etc. }\end{array}$ & $\begin{array}{l}\text { Improve urban } \\
\text { infrastructure and } \\
\text { urban amenities, } \\
\text { stimulating urban } \\
\text { growth, urban export } \\
\text { growth, drinking } \\
\text { water, infrastructure, } \\
\text { migration, resource } \\
\text { use etc. }\end{array}$ \\
\hline $\begin{array}{l}\text { Encouraging the } \\
\text { private sector to } \\
\text { participate and } \\
\text { innovate in the } \\
\text { growth process }\end{array}$ & $\begin{array}{l}\text { Developing } \\
\text { incentives for } \\
\text { businesses that make } \\
\text { use of low-skilled } \\
\text { labor force, } \\
\text { encouraging the } \\
\text { growth of the } \\
\text { informal economy, } \\
\text { businesses that } \\
\text { innovate in value } \\
\text { addition of } \\
\text { agricultural products }\end{array}$ & $\begin{array}{l}\text { Developing } \\
\text { incentives for } \\
\text { businesses that } \\
\text { innovate in value } \\
\text { addition of } \\
\text { agricultural products, } \\
\text { businesses that } \\
\text { innovate on } \\
\text { agriculture input } \\
\text { development }\end{array}$ & $\begin{array}{l}\text { Developing } \\
\text { incentives for } \\
\text { high-tech businesses } \\
\text { that innovate on } \\
\text { climate and } \\
\text { environmental issues } \\
\text { to increase global } \\
\text { competitiveness }\end{array}$ \\
\hline
\end{tabular}


sources in their income portfolio (Chandrasekhar \& Mehrotra, 2016). Livelihood diversification is a common strategy among the smallholders to ensure that they can make a basic living and insure themselves against unanticipated shocks. However, since the rural non-farm sector has not grown as fast as the urban non-farm sector, households that are locked into the rural non-farm sector due to credit or labor market constraints have not seen their non-farm incomes rise as quickly.

One of the simple ways to increase access to non-farm goods and labor markets is through investments in rural infrastructure (S. Aggarwal, 2018). Infrastructure investments such as roads that connect villages to towns or the development of interstate highways lower costs of transport and reduce costs related to relocation when laborers move between low productive and high productive regions. Also, investments in infrastructure such as power and irrigation help improve labor productivity on the farm, thus creating the impetus to move underemployed labor out of agriculture (Asher \& Novosad, 2018). In lagging states, rural infrastructure along with investments in human capital are critical for enabling catch-up growth. Programs such as the MGNREGA have been vital to improving the bargaining position of agricultural laborers in these areas and increasing income security. However, without proper credit markets, individuals may not be able to save, invest or spend these incomes (R. M. Townsend, $1994,1995)$. Thus programs that seek to provide UBI for individuals may not prove useful for rural development if there is no rural infrastructure development. In agriculture-led states and urbanizing states, creating upstream and downstream market linkages to enable the flow of goods and labor from agriculture to the non-agricultural sectors is essential. For the agriculture-led growth states, incentivizing the food processing industry, the food fortification industry and other allied food and feed industries will help redistribute agricultural surplus towards more productive uses. In urbanizing states, linking technology development with agricultural inputs development and innovations along the food supply chain will provide stimulus for agricultural development (McCullough, Pingali, \& Stamoulis, 2008). Introducing labor-saving technologies will increase agriculture productivity and hence agriculture-related incomes. Food supply chain innovations will reduce food waste and increase price determination of agricultural produce, thus strengthening the linkages between urban growth and rural prosperity. Rural infrastructure that connects markets across states will be essential to facilitate greater flow of goods and labor in response to demand for the same. 


\subsubsection{Reducing Labor Market Frictions That Prevent the Flow of Underemployed Labor Towards More Productive Economic Opportunities}

In many countries across the world, urban growth due to ST brought with it an increase in rural to urban migration. In India, this rural to urban transition has been low even though urban wages have continued to increase faster than rural wages. There are four reasons for this. One, low availability of skills due to low human capital investments has led to greater underemployment in the agriculture sector. Two, the absence of appropriate human capital skills, firms tend to rely on signals such as access to caste networks rather than signals of worker productivity in their hiring process. In the absence of these networks, abled bodied youth may not find it feasible to migrate towards urban jobs. Three, the inability to find sources for reskilling based on market demand also prevents those who are underemployed to move towards more productive job opportunities that require complementary skills. Lastly, women's labor force participation has been reducing due to the lack of availability of good quality jobs, lack of child care support facilities as well as low safety during their commute and at their workplaces in urban areas (Lipton, 1980; Munshi, 2011; Munshi \& Rosenzweig, 2006). These factors tend to influence the ability of migrants to permanently move out of rural economy as well.

As we look ahead, reducing labor market frictions by imparting job skills to the rural population, increasing investments in human capital development through quality education and setting up employment exchanges to reduce the search costs will be required. One of the significant challenges to leverage the non-farm sector for rural prosperity is to improve the quality of jobs and to reskill the population. The rural nonfarm sector mostly contains odd jobs and petty employment opportunities that hire low-skilled workers. A large portion of urban workers, especially migrants, are mostly involved in informal employment. Greater investment in improving human capital, especially vocational skills tailored to the local industry requirements, is thus essential for the complete transformation. In the lagging states, creating employment exchanges that channel workers towards vocational training and up-skilling their populations will be important. In agriculture-led states, the key would be to incentivize entrepreneurship and reskill the agriculture labor force to 
work in the non-agricultural sector. In urbanizing states, increasing capacity of the education sector to absorb more students and improve the quality of education would be significant for creating a globally competitive labor force.

Regarding improving matches between labor and firms, employment exchanges in developed countries have enabled greater employment through the use of information and communication technologies (ICT). In developed countries, the gig economy, where people transact shortterm personalized labor services, has become a useful means for reducing search costs for labor services (Burtch, Carnahan, \& Greenwood, 2018; Graham, Hjorth, \& Lehdonvirta, 2017). In the longer term, investing in higher education institutions that contribute to national growth through $\mathrm{R} \& \mathrm{D}$ is essential to maintain global competitiveness. Reducing labor market frictions that prevent women from participating, such as increasing safety enforcement in transport and the workplace, changing gender norms around what constitutes women's work and increasing child care facilities to reduce their opportunity costs will be required. Bringing women into the economic growth process gives us an additional 50\% chance of success.

In the food systems approach, the non-farm sector can create jobs through the development of modern agricultural value chains. Employment in logistics like aggregation, storage, processing, and so on at the agribusiness upstream and food-related services such as restaurants downstream could potentially be leveraged as the channel of employment generation. Higher demand for agricultural inputs and related technologies would generate other livelihood avenues. As NCDs and climate change create new challenges for health, having access to good quality healthcare service providers will be important. This implies that there will be a need for more service providers and research and development into treating and curing NCDs. This will increase the demand for educational institutes that provide these services. Involving the private sector to organize resources for education sector development while monitoring their quality will be a crucial step in this direction. Also, investments in developing an R\&D focused labor force and creating opportunities for innovators to benefit from intellectual property rights will stimulate innovation by individuals and (or) research organizations. All these sectors will also be able to provide women with enhanced opportunities to be a part of the labor force. 


\subsubsection{Improving the Capacity of Urban Governance Bodies to Facilitate Urban Development and Climate Proof Major Cities}

Many rural settlements in lagging states now exhibit urban characteristics as reflected in the quality of dwelling or changing occupational patterns (Pradhan, 2013). The government, however, continues to govern them as rural areas, which not only inhibits their overall development but also presents a slower rate of rural transformation. These middle spaces, along with the rural-urban continuum, offer enormous growth potential. Since they are the center through which much of the non-farm livelihood creation happens, these spaces are essential in facilitating the labor transition during structural transformation. These spaces-many of them far from the metropolitan cities - could themselves turn into agglomeration economies, encouraging both the migration of labor and capital from surrounding areas (Mukhopadhyay, Zérah, Samanta, \& Maria, 2016). By providing services such as technological inputs to the neighboring rural areas, these peri-urban economies often bring greater economic dynamism into the local economy. India's subaltern urbanization, with the right provision of public infrastructure, could thus attract investment near the rural areas, create jobs, reduce the burden on major cities and provide a lifeline to the farmers to markets and modern technologies, thus stimulating economic growth, especially in lagging states.

Over the next 30 years, the key challenge for India will be to build sustainable cities. Cities, especially in urbanizing states, would need to host burgeoning urban populations and provide new avenues for non-farm growth while also ensuring food security for those who live in them. With regard to economic growth, supporting investments in public goods such as construction of a good quality transport sector and investments in developing climate-friendly and sustainable water and solid waste disposal systems, developing a city-wide disaster fund to reduce damages from uncertain climatic events and providing investments to develop human capital through health and education investments will be required. These types of investments will improve the quality of life in cities and thus encourage participation by businesses that drive urban growth and employment opportunities. As coastlines move inwards due to climate change, governments would also have to be prepared for urban displacements and its impact on urban food security. Relocation of those who are poor but live near the coastline should be a focus on urban development plans. 
Urban food security is another major issue for the future (Tacoli, Bukhari, \& Fisher, 2013). As weather changes increase uncertainty in food production, an increase in volatility of prices will also impact urban food security. Creating an investment climate that develops efficiencies along the urban food supply chains will be essential to reduce food and nutrient loss. Also, connecting local urban supply chain to the global food supply chain will be an essential strategy for maintaining urban food security. As incomes per capita in these areas increase, instituting safety net measures for the urban poor, such as UBI, employment insurance and health insurance, will be essential to ensure overall urban development and food security as we look ahead.

\subsubsection{Encouraging the Private Sector and Climate-Smart Citizens to Participate and Innovate in the Growth Process}

Hart $(1995,1997)$ shows that businesses pursuing sustainable development strategies and developing environmentally and socially responsible products have the potential to increase their long-term profitability and hence it is socially optimum for them to do so. As consumers become more conscious of sustainability as a brand and consumers demand more accountability from companies in their supply chain and labor hiring practices, developing the investment climate to encourage environmentally friendly business practices should be encouraged in India. Currently, many experts in India wrongly argue that the country should be allowed to continue along its emissions pathways since we cannot have economic development opportunities void of emissions. This type of short-term thinking can lead to significant economic losses in the future.

With regard to creating new employment opportunities for growth, creating an investment climate that encourages sustainable businesses and business practices is required. The private sector can play a role in both helping with climate change mitigation and economic development as long as they are incentivized with appropriate intellectual property rights and are guaranteed returns to their investments. Currently, regulation on the part of the government in the form of urban land ceiling rules, inflexible labor and employment policies and stringent bankruptcy laws create opportunities for rent-seeking on behalf of the government and increase the cost of doing business. Removing these hurdles while also incentivizing venture capital investments in developing sustainable businesses will be an essential step towards ensuring long-term economic development. 
Pingali and Aiyar (2018) suggest the integration of all individuals, firms and governments across countries into global carbon markets. The authors envision that this would help in climate mitigation in the following ways. First, individuals when financially motivated may be more likely to invest in climate-friendly technologies and purchase climate-friendly production. For example, farmers who invest in organic farms or sustainable agriculture practices can earn points from the carbon markets in addition to the revenues they make through the sales of these products. This, in turn, would incentivize firms to invest in environment-friendly technologies that lead to the development of low emissions goods and services (Lal et al., 2007; Lehmann, 2007; Lohmann et al., 2006; Montagnini \& Nair, 2004; Jindal et al., 2008). However, to benefit from such a decentralized process, governments need to play a role in monitoring and measurement. Research and development into satellite technology to monitor progress, providing public research services in areas where business development is not possible and penalizing those who cheat on these markets will encourage greater compliance in \& credibility of carbon trading (Fawcett, 2010; Lohmann et al., 2006). At the global level, governments can discuss progress made and set agenda on emissions reductions and clean up as we look ahead.

\subsection{Conclusion}

Through the various chapters in the book, we have shared the contradictions that have come to represent the India growth story. To start with, fast-growing per capita incomes have not been met with a similar pace in the reduction of either undernutrition or micronutrient deficiencies in the country. These nutritional deficiencies are outcomes of inadequate access to food (and nutrients), which are outcomes of low incomes per capita. Even as policy makers continue to fight the battle against this undernutrition, on the other end of the spectrum, the prevalence of obesity, an outcome of over-nutrition, has been on the increase. Obesity rates are keeping close pace with the growth in per capita incomes even as undernutrition reduction remains a sticky challenge. The significant fallout of increasing obesity is the risk it poses for the growth of non-communicable diseases (NCD). In combination with the growing triple burden of malnutrition, increasing incidence of NCDs poses an exponential threat for economic and health security for the future food systems in India. Second, economic 
growth and increasing household incomes are known to be necessary for improving nutritional outcomes. Higher purchasing power enables a better command over household resources and hence improves access to better quality food. In line with this hypothesis, in states with high economic growth, policy makers have been successful in improving food security and reducing undernutrition. However, these states now face the challenge of tackling over-nutrition and NCDs related to this malnutrition. In states with low incomes per capita, on the other hand, high undernutrition persists. Even though there have been a large number of interventions focused on reducing this nutrition burden across the country, progress towards achieving the sustainable development goal of zero hunger and malnutrition has been slow. Thus, this regional inequality in nutritional outcomes is also reflected in the regional (state-wise) disparities in economic growth.

Third, within a state, the pace of household income growth and economic development has been determined by the structural transformation strategy chosen by the state for its development. The success of these strategies in enabling state-wise economic transformation has depended upon resource endowments of the states, global and local demand as well as their political priorities. Stark differences in regional development patterns have arisen in part due to differences in comparative advantages across states that have been based on access to agro-ecological zones, natural resource endowments, differences in institutional capacity and preferences for certain types of development strategies. These differences have mediated the speed of economic transformation across states. This has caused the country to develop such that some states now resemble low-income countries from sub-Saharan Africa while other states look more similar to high-income countries from Latin America. Fourth, the primary driver of this growing regional inequality has been the continued reliance of agricultural development strategies on staple grain production-driven growth. By focusing on staples as the foundation for agricultural development and therefore economic growth, national economic development policy has inadvertently created and entrenched regional disparities in growth. While the national staple grain promoting policies played an important role to ensure calorie sufficiency across the country, it also inhibited diversification of the food systems, reduced local nutrient availability and led to the faster development of regions with comparative advantages in staple crop production vis-à-vis others. Widening regional income inequality has 
reduced access and affordability of different nutrients in household diets and contributed to the phenomenon of undernutrition in some parts of the country and rising obesity in other parts. These differences are also reflected in disparities in regional development trajectories, employment patterns, occupational patterns and incomes.

Looking ahead, we see new opportunities and challenges for the current food systems. First, higher demand for diet diversity will create new avenues for growth through diversification in the agricultural sector. Continued reliance on the staple grain policies that often lock smallholder farmers into staple grain production will prevent them from realizing net benefits from diversifying their farm production in response to the new demand. Thus, we have provided recommendations on how to facilitate the commercialization and diversification of the farm sector given these challenges. This commercialization and diversification, we believe, will be necessary for increasing on-farm nutrient availability. Technologies in agriculture can ease the land and labor constraints and increase nutrient availability in food systems provided that threats from climate change are adequately addressed. Investing in both staple and non-staple production technologies that are climate sensitive and environmentally friendly will be an important adaptation measure against the threats of climate change on the viability of the agricultural system. Improving efficiency in food supply chains is also vital for increasing nutrient availability and for linking urban growth with rural prosperity. Second, given the projections of falling fertility and an increase in aging population in the country, health technologies will be useful in reducing NCD burden only if the malnutrition pandemic is put in check. This will require additional interventions that address access to good quality food, increasing dietary diversity, improving hygiene practices and increasing access to social protection policies. Third, in order to reduce economic disparities across regions, developing regionspecific growth strategies that are based on comparative advantages in states will be required. Also, investing in new comparative advantages that rely on the labor dividend and interventions that stimulate greater urban development will be required to maintain global competitiveness. For this to take place, increasing human capital through health and education interventions, reducing inequities in access to current labor markets and creating new avenues for the growth of the non-agricultural sector through entrepreneurship will be required. 


\section{REFERENCES}

Abraham, M., \& Pingali, P. (2017). Transforming smallholder agriculture to achieve the SDGs. In L. Riesgo, S. Gomez-Y-Paloma, \& K. Louhichi (Eds.), The role of small farms in food and nutrition security. Springer.

Aggarwal, P. K., \& Mall, R. K. (2002). Climate change and rice yields in diverse agro-environments of India. II. Effect of uncertainties in scenarios and crop models on impact assessment. Climatic Change, 52(3), 331-343. https://doi. org/10.1023/A:1013714506779

Aggarwal, S. (2018). Do rural roads create pathways out of poverty? Evidence from India. Journal of Development Economics, 133, 375-395. https://doi. org/10.1016/j.jdeveco.2018.01.004

Aker, J. C., \& Fafchamps, M. (2015). Mobile phone coverage and producer markets: Evidence from West Africa. The World Bank Economic Review, $29(2), 262-292$.

Anjana, R. M., Sudha, V., Nair, D. H., Lakshmipriya, N., Deepa, M., Pradeepa, R., ... Mohan, V. (2015). Diabetes in Asian Indians-How much is preventable? Ten-year follow-up of the Chennai Urban Rural Epidemiology Study (CURES-142). Diabetes Research and Clinical Practice, 109(2), 253-261. https://doi.org/10.1016/j.diabres.2015.05.039

Asher, S., \& Novosad, P. (2018). Rural roads and local economic development. Policy Research Working Paper No. WPS 8466, World Bank Group, Washington, DC.

Attanasio, O., Gomex, L. C., Heredia, P., \& Vera-hernández, M. (2005). The short-term impact of a conditional cash transfer on child health and nutrition in Colombia. Institute of Fiscal Studies.

Banerjee, R. R. (2015). Farmers' perception of climate change, impact and adaptation strategies: A case study of four villages in the semi-arid regions of India. Natural Hazards, 75(3), 2829-2845.

Behrman, J. R., Parker, S. W., \& Todd, P. E. (2011). Do conditional cash transfers for schooling generate lasting benefits?: A five-year followup of PROGRESA/ Oportunidades. Journal of Human Resources, 46(1), 203-236. https://doi. org/10.1353/jhr.2011.0028

Bennett, L. (1988). The role of women in income production and intra-household allocation of resources as a determinant of child nutrition and health. Food and Nutrition Bulletin, 10(3), 16-26.

Biran, A., Rabie, T., Schmidt, W., Juvekar, S., Hirve, S., \& Curtis, V. (2008). Comparing the performance of indicators of hand-washing practices in rural Indian households. Tropical Medicine \& International Health, 13(2), 278-285.

Biran, A., Schmidt, W.-P., Varadharajan, K. S., Rajaraman, D., Kumar, R., Greenland, K., ... Curtis, V. (2014). Effect of a behaviour-change intervention 
on handwashing with soap in India (SuperAmma): A cluster-randomised trial. The Lancet Global Health, 2(3), el45-e154. https://doi.org/10.1016/ S2214-109X(13)70160-8

Bollyky, T. J., Templin, T., Cohen, M., \& Dieleman, J. L. (2017). Lower-income countries that face the most rapid shift in noncommunicable disease burden are also the least prepared. Health Affairs, 36(11), 1866-1875. https://doi. org/10.1377/hlthaff.2017.0708

Buiatti, M., Christou, P., \& Pastore, G. (2013). The application of GMOs in agriculture and in food production for a better nutrition: Two different scientific points of view. Genes \& Nutrition, 8(3), 255-270. https://doi.org/10.1007/ s12263-012-0316-4

Burtch, G., Carnahan, S., \& Greenwood, B. N. (2018). Can you gig it? An empirical examination of the gig economy and entrepreneurial activity. Management Science, 64(12), 5497-5520.

Cawley, J. (2004). The impact of obesity on wages. The Journal of Human Resources, 39(2), 451. https://doi.org/10.2307/3559022

Cawley, J. (2010). The economics of childhood obesity. Health Affairs, 29(3), 364-371. https://doi.org/10.1377/hlthaff.2009.0721

Cawley, J. (2015). An economy of scales: A selective review of obesity's economic causes, consequences, and solutions. Journal of Health Economics, 43, 244-268. https://doi.org/10.1016/j.jhealeco.2015.03.001

Cawley, J., \& Meyerhoefer, C. (2012). The medical care costs of obesity: An instrumental variables approach. Journal of Health Economics, 31(1), 219-230. https://doi.org/10.1016/j.jhealeco.2011.10.003

Chandrasekhar, S., \& Mehrotra, N. (2016). Doubling farmers' incomes by 2022. Economic \& Political Weekly, 51(18), 10-13.

Colchero, M. A., Rivera-Dommarco, J., Popkin, B. M., \& Ng, S. W. (2017). In Mexico, evidence of sustained consumer response two years after implementing a sugar-sweetened beverage tax. Health Affairs, 36(3), 564-571.

Colchero, M. A., Salgado, J. C., Unar-Munguia, M., Hernandez-Avila, M., \& Rivera-Dommarco, J. A. (2015). Price elasticity of the demand for sugar sweetened beverages and soft drinks in Mexico. Economics \& Human Biology, 19, 129-137.

Costa-Font, M., Gil, J. M., \& Traill, W. B. (2008). Consumer acceptance, valuation of and attitudes towards genetically modified food: Review and implications for food policy. Food Policy, 33(2), 99-111. https://doi.org/10.1016/j. foodpol.2007.07.002

Croppenstedt, A., Knowles, M., \& Lowder, S. K. (2017). Social protection and agriculture: Introduction to the special issue. Global Food Security, 16(2), 0-1. https://doi.org/10.1016/j.gfs.2017.09.006

Drèze, J., \& Khera, R. (2017). Recent social security initiatives in India. World Development, 98, 555-572. https://doi.org/10.1016/j.worlddev.2017.05.035 
Ellis, F. (1998). Household strategies and rural livelihood diversification. Journal of Development Studies, 35(1), 1-38. https://doi.org/10.1080/ 00220389808422553

Fawcett, T. (2010). Personal carbon trading: A policy ahead of its time? Energy Policy, 38(11), 6868-6876.

Fernald, L. C. H., Gertler, P. J., \& Neufeld, L. M. (2008). Role of cash in conditional cash transfer programmes for child health, growth, and development: An analysis of Mexico's Oportunidades. Lancet, 371(9615), 828-837. https:// doi.org/10.1016/S0140-6736(08)60382-7

Fischer, R., Byerlee, D., \& Edmeades, G. (2009). Can technology deliver on the yield challenge to 2050? In How to feed the world in 2050. Rome: FAO and Economic and Social Development Department.

Flachowsky, G., \& Aulrich, K. (2001). Nutritional assessment of feeds from genetically modified organism. Journal of Animal and Feed Sciences, 10(Suppl. 1), 181-194. https://doi.org/10.22358/jafs/70020/2001

Gentilini, U. (2015). Revisiting the "cash versus food" debate: New evidence for an old puzzle? The World Bank Research Observer, 31(1), 135-167.

Graham, M., Hjorth, I., \& Lehdonvirta, V. (2017). Digital labour and development: Impacts of global digital labour platforms and the gig economy on worker livelihoods. Transfer: European Review of Labour and Research, 23(2), 135-162.

Gross-Camp, N. D., Few, R., \& Martin, A. (2015). Perceptions of and adaptation to environmental change in forest-adjacent communities in three African nations. International Forestry Review, 17(2), 153-164.

Handa, S., \& Davis, B. (2006). The experience of conditional cash transfers in Latin America and the Caribbean. Development Policy Review, 24(5), 513-536. https://doi.org/10.1111/j.1467-7679.2006.00345.x

Hart, S. L. (1995). A natural-resource-based view of the firm. Academy of Management Review, 20(4), 986-1014.

Hart, S. L. (1997). Beyond greening: Strategies for a sustainable world. Harvard Business Review, 75(1), 66-77.

Jensen, R. (2010). The (perceived) returns to education and the demand for schooling. Quarterly Journal of Economics, 125(2), 515-548.

Jensen, R. (2012). Do labor market opportunities affect young women's work and family decisions? Experimental evidence from India. The Quarterly Journal of Economics, 127(2), 753-792. https://doi.org/10.1093/qje/qjs002

Jindal, R., Swallow, B., \& Kerr, J. (2008, May). Forestry-based carbon sequestration projects in Africa: Potential benefits and challenges. Natural Resources Forum, 32(2), 116-130.

Kennedy, E., \& Peters, P. (1992). Household food security and child nutrition: The interaction of income and gender of household head. World Development, 20(8), 1077-1085. https://doi.org/10.1016/0305-750X(92)90001-C 
Khera, R. (2006). Mid-day meals in primary schools: Achievements and challenges. Economic and Political Weekly, 41(46), 4742-4750. Retrieved from http://www.jstor.org/stable/4418915

Lal, R., Follett, R. F., Stewart, B. A., \& Kimble, J. M. (2007). Soil carbon sequestration to mitigate climate change and advance food security. Soil Science, 172(12), 943-956.

Lee, L., Rosenzweig, M. R., \& Pitt, M. M. (1997). The effects of improved nutrition, sanitation, and water quality on child health in high-mortality populations. Journal of Econometrics, 77(1), 209-235. https://doi.org/10.1016/ S0304-4076(96)01813-1

Lehmann, J. (2007). A handful of carbon. Nature, 447(7141), 143.

Leroy, J. L., Ruel, M., \& Verhofstadt, E. (2009). The impact of conditional cash transfer programmes on child nutrition: A review of evidence using a programme theory framework. Journal of Development Effectiveness, 1(2), 103-129. https://doi.org/10.1080/19439340902924043

Lipper, L., Thornton, P., Campbell, B. M., Baedeker, T., Braimoh, A., Bwalya, M., ... Torquebiau, E. F. (2014). Climate-smart agriculture for food security. Nature Climate Change, 4(12), 1068-1072. https://doi.org/10.1038/ nclimate 2437

Lipton, M. (1980). Migration from rural areas of poor countries: The impact on rural productivity and income distribution. World Development, $8(1), 1-24$. https://doi.org/10.1016/0305-750X(80)90047-9

Lobell, D. B., Schlenker, W., \& Costa-Roberts, J. (2011). Climate trends and global crop production since 1980. Science, 333(6042), 616-620.

Lohmann, L., Hällström, N., Österbergh, R., \& Nordberg, O. (2006). Carbon trading: A critical conversation on climate change, privatisation and power. Uppsala: Dag Hammarskjöld Centre. Retrieved from https://www.tni.org/ en/publication/carbon-trading

Maitra, C., \& Rao, D. S. P. (2015). Poverty-food security nexus: Evidence from a survey of urban slum dwellers in Kolkata. World Development, 72, 308-325. https://doi.org/10.1016/j.worlddev.2015.03.006

Mangyo, E. (2008). The effect of water accessibility on child health in China. Journal of Health Economics, 27(5), 1343-1356.

McCullough, E. B., Pingali, P., \& Stamoulis, K. G. (2008). Small farms and the transformation of food systems: An overview. In E. B. McCullough, P. L. Pingali, \& K. G. Stamoulis (Eds.), The transformation of agri-food systems: Globalisation, supply chains, and smallholder farmers (pp. 3-46). Rome: FAO.

Meenakshi, J. V., Johnson, N. L., Manyong, V. M., DeGroote, H., Javelosa, J., Yanggen, D. R., ... Meng, E. (2010). How cost-effective is biofortification in combating micronutrient malnutrition? An ex ante assessment. World Development, 38(1), 64-75. https://doi.org/10.1016/j.worlddev.2009.03.014 
Mengistie, B., Berhane, Y., \& Worku, A. (2013). Household water chlorination reduces incidence of diarrhea among under-five children in rural Ethiopia: A cluster randomized controlled trial. PLoS One, 8(10), e77887.

Mittal, S., \& Mehar, M. (2012). How mobile phones contribute to growth of small farmers? Evidence from India. Quarterly Journal of International Agriculture, 51(3), 227-244.

Montagnini, F., \& Nair, P. K. R. (2004). Carbon sequestration: An underexploited environmental benefit of agroforestry systems. In New vistas in agroforestry (pp. 281-295). Dordrecht: Springer. Retrieved from http://citeseerx.ist.psu. edu/viewdoc/download?doi=10.1.1.456.8246\&rep=repl \&type=pdf

Mukhopadhyay, P., Zérah, M.-H., Samanta, G., \& Maria, A. (2016). Understanding India's urban frontier: What is behind the emergence of census towns in India? The World Bank. https://doi.org/10.1596/1813-9450-7923

Munshi, K. (2011). Strength in numbers: Networks as a solution to occupational traps. Review of Economic Studies, 78(3), 1069-1101. https://doi.org/ $10.1093 / \mathrm{restud} / \mathrm{rdq} 029$

Munshi, K., \& Rosenzweig, M. (2006). Traditional institutions meet the modern world: Caste, gender, and schooling choice in a globalizing economy. American Economic Review, 96(4), 1225-1252. https://doi.org/10.1257/aer.96.4.1225

Myers, S. S., Smith, M. R., Guth, S., Golden, C. D., Vaitla, B., Mueller, N. D., ... Huybers, P. (2017). Climate change and global food systems: Potential impacts on food security and undernutrition. Annual Review of Public Health, 38(1), 259-277. https://doi.org/10.1146/annurev-publhealth-031816-044356

Myers, S. S., Zanobetti, A., Kloog, I., Huybers, P., Leakey, A. D. B., Bloom, A. J., ... Usui, Y. (2014). Increasing $\mathrm{CO}_{2}$ threatens human nutrition. Nature, $510(7503), 139-142$.

Padel, S., \& Foster, C. (2005). Exploring the gap between attitudes and behaviour: Understanding why consumers buy or do not buy organic food. British Food Journal, 107(8), 606-625. https://doi.org/10.1108/00070700510611002

Pingali, P., \& Aiyar, A. (2018). Food, agriculture, and nutrition policy: Looking ahead to 2050. In P. P. Rachid Serraj (Ed.), Agriculture and food systems to 2050. World Scientific Publishing.

Pingali, P., Mittra, B., \& Rahman, A. (2016, March). The bumpy road from food to nutrition security-Slow evolution of India's food policy. https://doi. org/10.1016/j.gfs.2017.05.002

Pingali, P., \& Rosegrant, M. W. (1995). Agricultural commercialization and diversification: Processes and policies. Food Policy, 20(3), 171-185. https://doi. org/10.1016/0306-9192(95)00012-4

Pinstrup-Andersen, P. (2009). Food security: Definition and measurement. Food Security, 1(1), 5-7. https://doi.org/10.1007/s12571-008-0002-y 
Pradhan, K. C. (2013). Unacknowledged urbanisation. Economic and Political Weekly. Retrieved from https://www.epw.in/journal/2013/36/special-articles/unacknowledged-urbanisation.html

Qaim, M., Stein, A. J., \& Meenakshi, J. V. (2007). Economics of biofortification. Agricultural Economics, 37(s1), 119-133.

Rah, J. H., Cronin, A. A., Badgaiyan, B., Aguayo, V. M., Coates, S., \& Ahmed, S. (2015). Household sanitation and personal hygiene practices are associated with child stunting in rural India: A cross-sectional analysis of surveys. BMJ Open, 5(2), e005180.

Rao, C. N., Pray, C. E., \& Herring, R. J. (2018). Biotechnology for second green revolution in India: Overview of issues. In R. N. Chandrashekhar, C. E. Pray, \& R. J. Herring (Eds.), Biotechnology for a second green revolution in India (pp. 45-74). New Delhi: Academic Foundation.

Ravallion, M. (2002). On the urbanization of poverty. Journal of Development Economics, 68(2), 435-442. https://doi.org/10.1016/S0304-3878(02)00021-4

Reardon, T., \& Timmer, P. C. (2007). Chapter 55 Transformation of markets for agricultural output in developing countries since 1950: How has thinking changed? In Handbook of agricultural economics (Vol. 3, pp. 2807-2855). Elsevier. https://doi.org/10.1016/S1574-0072(06)03055-6

Reddy, A. (2016). Impact of e-markets in Karnataka, India. Indian Journal of Agricultural Marketing, 30(2), 31-44.

Schlenker, W., \& Roberts, M. J. (2009). Nonlinear temperature effects indicate severe damages to US crop yields under climate change. Proceedings of the National Academy of Sciences, 106(37), 15594-15598.

Sinha, S. K., \& Swaminathan, M. S. (1992). Deforestation, climate change and sustainable nutrition security: A case study of India. In N. Myers (Ed.), Tropical forests and climate (pp. 201-209). Dordrecht: Springer Netherlands. https:// doi.org/10.1007/978-94-017-3608-4_20

Spears, D., Ghosh, A., \& Cumming, O. (2013). Open defecation and childhood stunting in India: An ecological analysis of new data from 112 districts. PLoS One, 8(9), e73784. https://doi.org/10.1371/journal.pone.0073784

Steiner, J. L., Briske, D. D., Brown, D. P., \& Rottler, C. M. (2018). Vulnerability of Southern Plains agriculture to climate change. Climatic Change, 146(1-2), 201-218.

Tacoli, C., Bukhari, B., \& Fisher, S. (2013). Urban poverty, food security and climate change. Human Settlements Working Paper No. 37.

Thow, A. M., Downs, S. M., Mayes, C., Trevena, H., Waqanivalu, T., \& Cawley, J. (2018). Policy and practice Fiscal policy to improve diets and prevent noncommunicable diseases: From recommendations to action. Bull World Health Organ, 96(February), 201-210. https://doi.org/10.2471/BLT.17.195982 
Timmer, P. C. (1988). Chapter 8 The agricultural transformation. Handbook of Development Economics, 1, 275-331. https://doi.org/10.1016/S15734471(88)01011-3

Townsend, R. M. (1994). Risk and insurance in village India. Econometrica, $62(3), 539-591$.

Townsend, R. M. (1995). Consumption insurance: An evaluation of risk-bearing systems in low-income economies. Journal of Economic Perspectives, 9(3), 83-102. https://doi.org/10.1257/jep.9.3.83

Open Access This chapter is licensed under the terms of the Creative Commons Attribution 4.0 International License (http://creativecommons.org/licenses/ by $/ 4.0 /$ ), which permits use, sharing, adaptation, distribution and reproduction in any medium or format, as long as you give appropriate credit to the original author(s) and the source, provide a link to the Creative Commons licence and indicate if changes were made.

The images or other third party material in this chapter are included in the chapter's Creative Commons licence, unless indicated otherwise in a credit line to the material. If material is not included in the chapter's Creative Commons licence and your intended use is not permitted by statutory regulation or exceeds the permitted use, you will need to obtain permission directly from the copyright holder.

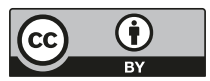

